\title{
Should local public employment services be merged with local social benefit administrations?
}

\author{
Christian Holzner • Sonja Munz
}

Accepted: 12 September 2012 / Published online: 6 October 2012

(C) Institut für Arbeitsmarkt- und Berufsforschung 2012

\begin{abstract}
The German Federal government has allowed local governments of some regions (Approved Local Providers) to be solely responsible for the care of unemployment benefit II recipients. In the remaining regions Joint Local Agencies were formed, where the local social benefit administrations work together with the local public employment services. We find that despite positive self-selection Approved Local Providers do not perform better than Joint Local Agencies. Even more interestingly, using a unique data set on organisational characteristics we are able to show that the organisational features implemented primarily by Approved Local Providers are positively correlated with the job finding probability of the unemployment benefits II recipients. Thus, local governments that self-selected into Approved Local Providers seem to have implemented a better organisational structure. However, their relatively poor performance overall compared to Joint Local Agencies suggests that they underestimated the benefits of having the local public employment service merged with the local social benefit administration.
\end{abstract}

Keywords Organisation · labour market integration · evaluation

JEL Classification I38 · J64 · C31

C. Holzner $(\bowtie)$

Ifo Institute, Poschingerstr. 5, 81679 Munich, Germany

e-mail: holzner@ifo.de

S. Munz

Munich University of Applied Sciences, Schachenmeierstrasse

35, 80636 Munich, Germany

e-mail: sonja.munz@hm.edu Sollten kommunale Arbeitsvermittlungsagenturen mit
der kommunalen Sozialverwaltung fusioniert werden?

Zusammenfassung Die Deutsche Bundesregierung hat ausgewählten Kommunen (zugelassene kommunale Träger zkT) die Möglichkeit eröffnet, sich eigenverantwortlich um die Betreuung erwerbsfähiger Hilfebedürftiger (sog. Hartz IV Empfänger) zu kümmern. In den restlichen Kommunen wurden sogenannte Arbeitsgemeinschaften (ARGEn) von Arbeitsagenturen und Kommunen gegründet, in denen die kommunale Sozialverwaltung mit den Arbeitsagenturen zusammenarbeitet. Doch trotz der positiven Selbstselektion der zkT-Regionen weisen diese für die erwerbsfähigen Hilfebedürftigen keine höheren Übergangsraten auf als die ARGEn. Um einen tieferen Einblick in die organisatorische Struktur der relevanten Institutionen zu gewinnen, wurde ein spezifischer Datensatz genutzt, der wichtige Merkmale aller Arbeitsagenturen enthält. Die Tatsache, dass zkT überwiegend Organisationsstrukturen verwenden, die positiv korreliert sind mit höheren Erfolgsquoten beim Übergang in die Erwerbstätigkeit von Arbeitslosengeld IIEmpfängern, deutet darauf hin, dass die Verantwortlichen auf regionaler Ebene, die das zkT Modell gewählt haben, die für die Arbeitslosengeld II-Empfänger erfolgreichere Organisationsform gefunden haben. Allerdings bedeutet die relativ schlechte Performance der zkT-Regionen im Vergleich zu den ARGEn-Regionen - wie auf Basis des TreatmentEffekts unter Kontrolle der Organisationsmerkmale gezeigt wurde -, dass auch die bessere Organisationsform nicht die Nachteile kompensieren kann, die sich aus der integrierten Form der kommunalen Arbeitsvermittlung und der Sozialverwaltung ergeben haben.

Schlüsselwörter Organisation · Arbeitsmarktintegration · Evaluation 


\section{Introduction}

Getting social assistance recipients back to work has been top on the agenda of many European governments over the last two decades. The aim to simultaneously enhance both flexibility and security in the labour market has led the European Commission together with the Member States to develop a set of common principles for flexicurity. The principle to provide social assistance recipients with the means necessary to find a job and to achieve an acceptable living standard requires a higher degree of cooperation between local public employment services and social benefit administrations. Some European countries have decentralised their public employment services to increase the cooperation with social benefit administrations at the local level, others have merged public employment services and social benefit administrations (European Commission 2006). In 2002 the United Kingdom merged public employment services and social benefit administrations (Jobcentre Plus). Finland started to integrate the labour and the social affairs administrations into joint services (Duuri) in 2002 (Genova 2008). In Denmark the 2007 reorganisation of local and regional governments included the integration of public employment services and county-led social benefit administrations into 91 one-stop-shop jobcentres (Lindsay and McQuaid 2008). Public employment services and social benefit administrations were also merged in the Netherlands (Location for Work and Income) and in France (France emploi) in 2009 (European Commission 2009).

We use a policy experiment of the Hartz IV Reform in Germany to evaluate whether merging public employment services and social benefit administrations improves the job finding probability of unemployment benefit II recipients (see Table 1). The Hartz IV reform that came into effect in 2005 has created new institutions for social assistance and unemployment assistance recipients. Before the reform, Germany had two separate institutions; the local social benefit administrations, which cared for social assistance recipients, and the local public employment services, which cared for unemployment assistance recipients. Under Hartz IV employable unemployed in need, who belong to one of the two groups and their employable partners are now named unemployment benefit II recipients. The predominate organisational form, which cares for unemployment benefit II recipients is called Joint Local Agency (JLA), since it constitutes a joint venture between the local public employment service and the local social benefit administration. Due to the experiment, 69 out of 442 regions created new institutions named Approved Local Providers (ALP) by enlarging the former local social benefit administrations.

We compare the performance of JLAs with the performance of ALPs after the Hartz IV reform in an attempt to identify the better institution. To control for potential selfselection into the treatment "Approved Local Provider" we use an instrumental variable approach. As an instrument we use information about the involvement of local political representatives in the German County Association ("Deutscher Landkreistag"). The German County Association is a political lobbying institution that promoted the introduction of ALPs in all German regions and that had a large influence on which regions applied for becoming an ALP, but has no influence on the regional labour market performance.

The OLS-estimate and the IV-estimate for the treatment effect of being an ALP (without controlling for organisational characteristics) are insignificant, but they indicate that unemployment benefit II recipients in regions with ALPs have lower unemployment to employment transition rates than unemployment benefit II recipients in regions with JLAs. We also find that regions that later became ALPs had slightly better labour market conditions before the Hartz IV reform. Thus, despite the evidence that local governments in regions with better labour market conditions prior to the Hartz IV reform selected themselves into being ALPs, regions with ALPs do not perform better than JLAs.

To gain further insight into the organisational features that determine the success of an institution, we are able to use a unique dataset on the major organisational characteristics of all job centres. Many organisational features are not unique to one of the two institutions, but can be found in either ALPs or JLAs. Thus, our dataset allows us to shed some light on the factors that determine a successful institution. We find that unemployment benefit II recipients in regions where job centres use a generalised case management approach have a higher job finding probability compared to unemployment benefit II recipients in regions where job centres use a specialised case management approach. ALPs predominantly use the more successful generalised case management approach while JLAs primarily use a specialised case management approach. Moreover, ALPs mostly have their own vacancy recruitment service while JLAs frequently use the vacancy recruitment service of the local public employment service that is also responsible for unemployment benefit I recipients. In addition, ALPs more often use an integrated matching approach, where the vacancy recruitment service generally communicates new vacancies to case managers and does not primarily match unemployment benefit II recipients and job vacancies on its own. Both measures that are primarily used by ALPs are positively correlated with higher job finding rates.

The fact that Approved Local Providers predominantly implemented an organisational structure that is positively correlated with the job finding probability of unemployment benefit II recipients indicates that regions that selfselected into ALPs seem to have implemented an organisational structure that is better suited to integrate unemployment benefit II recipients into the labour market. However, the relatively poor performance of ALPs compared to 
JLAs - as shown by the treatment effect after controlling for organisational characteristics-indicates that having a better organisational structure does not compensate for the lost benefits of having the local public employment service and local social benefit administration integrated.

At the same time and independently from us Boockmann et al. (2010) analysed the same experiment. They also find a positive effect of JLAs. Boockmann et al. (2010) use individual data, since they are worried that the composition of long-term unemployed in ALPs differs from the composition of the long-term unemployed in JLAs. They show that neither of the two institutions had an easier to integrate group of unemployment benefit II recipients. The drawback of using individual data is that they are only able to use data of 154 regions, while our dataset includes 409 out of 442 regions.

The paper is organised as follows. Section 2 describes the changes in labour market institutions and the policy experiment resulting from the Hartz IV reform. In Sect. 3 we provide evidence for positive self-selection into being ALPs by comparing the labour market conditions in regions with ALPs and JLAs before the Hartz IV reform. Section 4 describes the data used. In Sect. 5 we first present some basic descriptive evidence and OLS estimates for the correlation between the job finding probability of unemployment benefit II recipients and the indicator variable "being cared for by an ALP". We then discuss the instrument we use to account for positive self-selection into being Approved Local Providers and present the IV estimates of the treatment effect of being cared for by an ALP. In Sect. 6 we account for the differences in the organisational structure implemented by job centres and investigate the role of these organisational characteristics for the number of unemployment benefit II recipients finding a job each month. Section 7 concludes.

\section{Labour market institutions resulting from the Hartz reform}

Like in other European countries, the local public employment services and the local social benefit administrations in Germany were merged in the course of a labour market reform in order to ensure a single contact point for unemployment benefit II recipients. The so-called Hartz reforms (Hartz I, II, III, IV) implied a substantial change for the German welfare state in many respect. These reforms were implemented step by step between 2003 and 2005 (see Jacobi and Kluve (2007) for a more detailed description of all four Hartz reforms). While the Hartz IV reform constitutes a comprehensive modification of the unemployment and social assistance schemes, the Hartz I-III reforms focused on relaxing regulations for temporary employment and labour leasing, on modifying already existing active labour market policy instruments, and on the reorganisation of the Federal Employment Service.

To understand the institutional setup implemented by the Hartz IV reform it is important to understand the institutions behind the social and unemployment insurance scheme in Germany before the reform (for more details see Table 1). The Federal Employment Service is on behalf of the Federal Government responsible for the unemployment insurance system. Its local branches, the local employment services, take care of unemployment benefit I recipients. Before the Hartz IV reform the Federal Employment Service was also in charge of unemployment assistance scheme, which was financed by federal taxes and not by contributions. The regions (i.e., cities and districts) administered and paid for social assistance. The regions are governed by city or district counsels and represented by majors and are independent from the Federal and States governments. The local social benefit administrations that cared for social assistance recipients ${ }^{1}$ before the Hartz IV reform were also independent from the local employment services.

The Hartz IV reform regulated the consolidation of unemployment assistance and social assistance to form one basic income support system for persons who are fit for employment and at the same time in need of assistance. Now all employable people in need have access to the same benefits and receive assistance subject to the same rules. One of the aims of the Hartz IV reform was to ensure that employable people receive assistance under one roof. Thus, unemployed benefit II recipients no longer have to contact different authorities, like the local public employment service for information on job openings and the local benefit administration for questions regarding their benefit claims.

The regions (cities and districts) receive the financial resources for the unemployment benefit II payments from the German Federation. The expenses for housing and heating for unemployment benefit II recipients have to be covered by the regions themselves.

The integration of social and unemployment assistance under Hartz IV opened up the question of responsibility for the newly formed group of unemployment benefit II recipients. The regions in charge of the local social benefit administration feared to lose autonomy in budgetary and personnel matters if they gave up such an important task. Especially the German County Association ("Deutscher Landkreistag"), supported by the majority of German States, campaigned for giving the local governments the sole responsibility for unemployment benefit II recipients, i.e., they campaigned for having the ALP institution implemented nationwide. The German County Association is the federal

\footnotetext{
${ }^{1}$ Employable people received social assistance either because they were not eligible for unemployment assistance or the level of unemployment assistance fell short of the minimum subsistence level.
} 


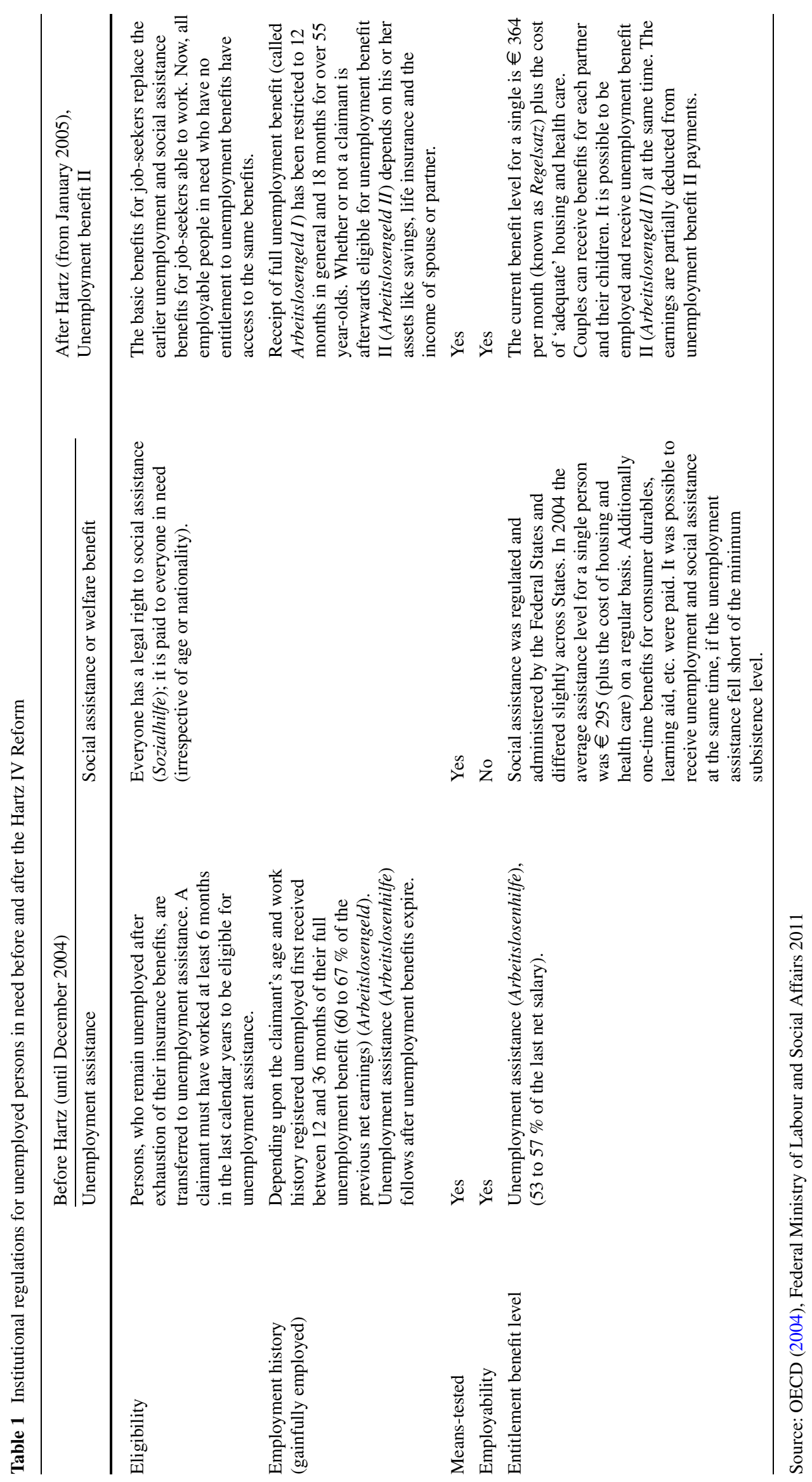


Association of German Counties and its main tasks are to promote regional government self-administration. As a lobbying institution, it tries to influence Federal and State level legislation that affects the regions. The Federal Government, however, which predominantly finances the social security system, favoured the JLA model, where a local public employment service and one or more regions (more precisely their local social benefit administrations) are merged and carry out their responsibilities in mutual cooperation. Due to the federal system in Germany, where the States have a veto right if the majority of the States oppose a law passed by the Federal Parliament, the Federal Government was forced to agree to a policy experiment, where 69 out of 442 regions were allowed to design the organisation and activation process for unemployment benefit II recipients in their job centres (ALPs) independent of the guidelines of the Federal Employment Agency. The remaining regions formed JLAs, where the local government and the Federal Employment Agency had to agree on the organisation of the local job centre. ${ }^{2}$ Given the guidelines of the Federal Employment Agency the local government has less scope to shape the organisation of a JLA according to its own agenda. The guidelines included controlling standards, guidelines for the use of active labour market policies and the requirement to implement the computer software of the Federal Employment Agency. Still there was scope for implementing different organisational structures. The descriptive statistics in Sect. 6 show the considerable diversity of the organisational structures implemented by JLAs (Fig. 1).

The number of 69 Approved Local Providers was chosen because the Federal Council of Germany (Bundesrat), which opposed the Federal Government's initial plan, is composed of 69 delegates of State Governments. Each of the States was allowed to nominate as many regions for the ALP-model as it has seats in the Federal Council of Germany. In order to be nominated by a State Government the regions had to apply. In total 70 regions applied for becoming ALPs. In some States the number of applicants was lower than the number of available slots. The unutilised slots were then allocated to those States that had excess applications.

The Federal Government agreed to turn this temporary experiment into a permanent one from January 2011 onward. In January 2012 additional 41 regions were allowed to become ALPs.

For the validity of our identification strategy it is important to note, that all other components of the public welfare system and the Hartz reforms-such as benefit entitlements,

\footnotetext{
${ }^{2}$ In 20 regions the Federal Employment Agency and the local government could not agree on the organisation. In these cases, the local employment agency and the local social benefit administration remained separate organisational bodies.
}

the tax-benefit system in general, and labour market institutions such as minimum wages and employment protectionapply equally to all regions irrespective of the job centre organisation.

\section{Labour market conditions before the Hartz IV reform}

The standard identification strategy would be to compare the development of the transition rates of unemployment benefit II recipients before and after the reform. Since we have no job finding rates for unemployment benefit II recipients before the Hartz IV reform, we cannot compare the regional transition rates before and after the reform. To identify a potential self-selection bias we can only compare the transition rates of all unemployed workers (including unemployment benefit recipients) in regions that later became ALPs with regions that later became JLA before the Hartz IV reform.

The descriptive statistics in Table 2 show that the regions with ALPs had on average slightly lower transition rates from unemployment to employment compared to regions with JLAs. Other labour market variables before the Hartz IV reform like the overall unemployment rates, the long-term unemployment rates (unemployed for more than one year) and the ratios of social and unemployment assistance recipients to the working age population suggest that regions that went on to become ALPs had lower unemployment rates, lower long-term unemployment rates, lower unemployment assistance recipient rates and lower social assistance recipient rates in the years 2000 until 2003. While the differences for unemployment rates, long-term unemployment rates and unemployment assistance recipient rates are not statistically significant, the differences in social assistance benefits recipient rates are highly significant. Prior to the Hartz IV reform unemployment benefit recipients and unemployment assistance recipients were cared for by the local public employment services, which are controlled by the Federal Employment Agency. ${ }^{3}$ Social assistance recipients, however, were cared for by local social benefit administrations, which are under the control of the local government. Since the regional authorities decided whether to apply for becoming an ALP or not, one would expect that the

\footnotetext{
${ }^{3}$ The transition rates from unemployment to employment apply to overall unemployment rates. Given that unemployed were exclusively cared for by the local public employment services the lower transition rates indicate that the local public employment services in regions that later became ALPs were not as good in integrating unemployed as in other regions. Given the relatively bad performance of the local public employment services local governments have an incentive to organise the activation process for unemployment benefit II recipients on their own, i.e., without the relatively bad performing local public employment services. We argue that avoiding this kind of bad selection is similar to positive self-selection.
} 


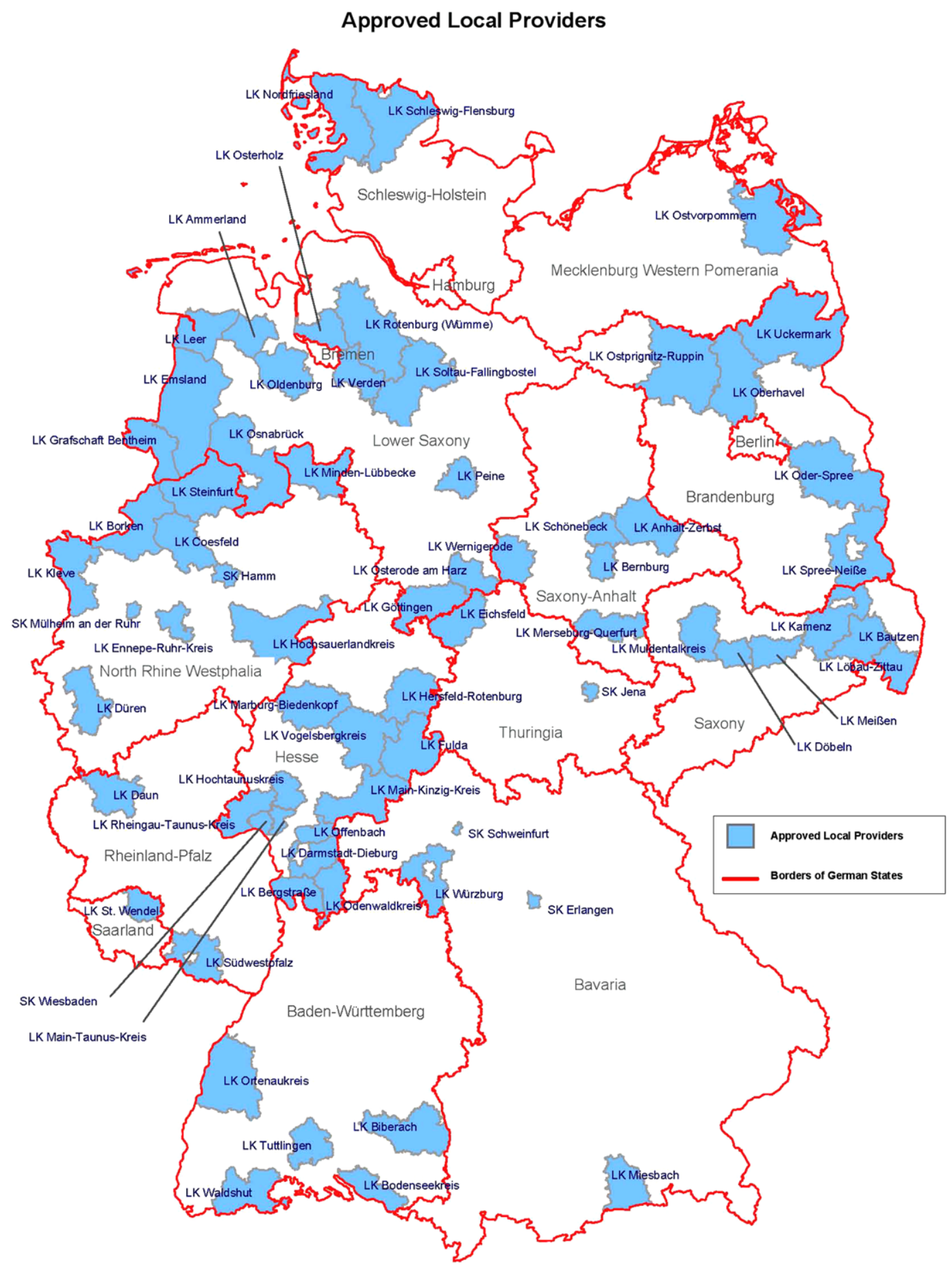

Fig. 1 Regional distribution of Approved Local Providers in 2007

local governments primarily looked at the social assistance recipient rates in order to evaluate whether they are better able to care for the unemployment benefit II recipients on their own compared to a joint venture with the local public employment service.

The significantly different social assistance recipient rates suggest some degree of positive self-selection of lo- cal governments into ALPs. The positive selection of regions with advantages in activating social assistance recipients is likely to lead to higher job finding rates in regions with ALPs and an upward biased estimate in the OLS regressions. We will therefore use an instrumental variable approach to correct for the potential self-selection bias. 
Table 2 Labour market conditions in regions of ALPs and JLAs in 2000-2003

\begin{tabular}{|c|c|c|c|c|}
\hline & 2000 & 2001 & 2002 & 2003 \\
\hline \multicolumn{5}{|c|}{ Unemployment to employment transition rate ${ }^{\mathrm{a}}$ (weighted by the number of unemployed per region) } \\
\hline ALP & $7.06[6.82 ; 7.29]$ & $6.70[6.47 ; 6.93]$ & $6.24[6.04 ; 6.45]$ & $6.23[6.04 ; 6.42]$ \\
\hline JLA & $7.18[6.80 ; 7.55]$ & $6.94[6.59 ; 7.29]$ & $6.61[6.30 ; 6.93]$ & $6.59[6.28 ; 6.89]$ \\
\hline \multicolumn{5}{|c|}{ Unemployment rate (weighted by the number of unemployed per region) } \\
\hline ALP & $9.22[8.05 ; 10.39]$ & $8.97[7.76 ; 10.19]$ & $9.21[8.04 ; 10.39]$ & $9.89[8.71 ; 11.06]$ \\
\hline JLA & $9.84[9.34 ; 10.34]$ & $9.61[9.10 ; 10.13]$ & $10.08[9.57 ; 10.59]$ & $10.81[10.3 ; 11.32]$ \\
\hline \multicolumn{5}{|c|}{ Long-term unemployment rate (weighted by the number of unemployed per region) } \\
\hline ALP & $3.44[3.01 ; 3.86]$ & $3.17[2.68 ; 3.66]$ & $3.11[2.57 ; 3.64]$ & $3.41[2.82 ; 3.99]$ \\
\hline JLA & $3.68[3.48 ; 3.88]$ & $3.41[3.16 ; 3.58]$ & $3.41[3.18 ; 3.64]$ & $3.80[3.54 ; 4.06]$ \\
\hline \multicolumn{5}{|c|}{ Unemployment assistance recipient rate ${ }^{\mathrm{a}}$ (weighted by the working age population per region) } \\
\hline ALP & $2.64[2.14 ; 3.14]$ & $2.67[2.12 ; 3.22]$ & $3.03[2.41 ; 3.65]$ & $3.61[2.90 ; 4.31]$ \\
\hline JLA & $2.84[2.63 ; 3.05]$ & $2.87[2.64 ; 3.09]$ & $3.29[3.03 ; 3.54]$ & $3.91[3.62 ; 4.21]$ \\
\hline \multicolumn{5}{|c|}{ Social assistance recipient rate ${ }^{a}$ (weighted by the working age population per region) } \\
\hline ALP & $4.18[3.82 ; 4.55]^{* *}$ & $4.16[3.80 ; 4.52]^{* *}$ & $4.30[3.92 ; 4.68]^{* *}$ & $4.36[3.99 ; 4.73]^{* *}$ \\
\hline JLA & $5.28[4.96 ; 5.60]^{* *}$ & $5.35[5.03 ; 5.66]^{* *}$ & $5.47[5.16 ; 5.79]^{* *}$ & $5.61[5.30 ; 5.93]^{* *}$ \\
\hline
\end{tabular}

${ }^{a}$ The unemployment and social assistance rate are weighted in percent of working age population (18 to 64 year olds). Unemployment assistance recipients are weighted similarly. Source: Own calculations based on data from the Federal Employment Office

Confidence intervals with $*$ and $* *$ indicate significance at a $5 \%$ and $1 \%$ level, respectively

\section{Description of the data}

The Hartz IV reform implemented completely new institutions to care for and to activate the unemployment benefit II recipients. Given the completely new organisations and the newly defined group of unemployment benefit II recipients (see details in Sect. 2), it was not surprising that the job centres needed some time to get started. Within the first half year all job centres had filed the applications of previous social and unemployment assistance recipients and of recent unemployment benefit II recipients. In the first half of 2006 the workload of all job centres converged to the new steady state level and in the second half of 2006 all job centres managed to report the required statistics to the Federal Employment Agency.

The monthly unemployment to employment transition data used for the evaluation was retrieved from unemployment and employment stock datasets for the period July 2006 until May 2007. Individuals that were registered in month $t$ as unemployment benefit II recipients without a job and in month $t+1$ as employed with or without in-work benefits are counted as transitions from unemployment into employment. In order to obtain the correct number of transitions into employment, we had to subtract transitions of unemployment benefit II recipients into public employment schemes and other active labour market policy instruments whose participants are counted as employed workers in the official statistics. ${ }^{4}$ In order to avoid any bias resulting from missing data for some ALPs we have restricted our sample to the first half of 2007.5

We combine the monthly transition data obtained from the Federal Employment Agency with administrative unemployment and vacancy data on the job centre level and with the organisation data from a survey conducted among the executive managers of job centres. This unique dataset (IAW-SGB-II-Organisationserhebung ${ }^{6}$ ) includes variables that characterise each job centre's organisational structure, e.g. the type of case management, the intensity and speed of activation, the counselling concept, the vacancy recruitment and the distribution process. Further regional background variables like the degree of urbanisation and the population size of a region are obtained from the Federal Statistical Office. Table A.1 in the Appendix provides some summary statistics of the dataset used for the subsequent analysis.

\footnotetext{
${ }^{4}$ Unfortunately, only the transitions for the official unemployment to employment transitions are available for later periods, but not the data for transitions into public employment schemes and other active labour market policy instruments. See http://statistik. arbeitsagentur.de/Navigation/Statistik/Statistische-Analysen/SGB-IIKennzahlen/Uebergangsanalysen/Zu-den-Daten-Nav.html.

${ }^{5}$ Boockmann et al. (2010) use the same time period for the identical reason.

${ }^{6}$ For more details (in German) see: http://www.bmas.de/portal/18638/ property $=$ pdf.
} 
Since the status of being an ALP and the organisational characteristics do not change over the time under investigation, we do not gain anything by using the panel structure of the dependent variable. We therefore take the averages of the monthly data for our OLS and IV regressions.

\section{The treatment effect of being an Approved Local Provider}

The overall treatment effect of being an ALP is obtained by comparing the performance of ALPs with the performance of JLAs without controlling for organisational characteristics. Comparing the weighted averages of the job finding rates of unemployment benefit II recipients (weighted by the number of unemployment benefit II recipients in each region) shows that the job finding rate in regions with ALPs is higher than in regions with JLAs. On average $3.98 \%$ of all unemployment benefit II recipients in regions with JLAs and $3.83 \%$ in regions with ALPs found a job each month. ${ }^{7}$ However, this difference can be driven by heterogeneity across regions. 62 out of 69 ALPs operate in rural regions, which generally have better labour market conditions. If we restrict our sample to rural regions only, JLAs with a job finding rate of $4.21 \%$ outperform ALPs with a rate of $3.83 \%$.

We further examine this relationship by controlling for observable regional characteristics that influence the job finding probability of unemployment benefit II recipients by estimating the following equation,

$$
\begin{aligned}
\ln y_{i}= & \beta_{0}+\beta_{1} I_{i}+\beta_{2} \ln u_{i, t-1}+\beta_{3} \ln v_{i, t-1} \\
& +\beta_{4} \ln u_{n i, t-1}+\beta_{5} \ln v_{n i, t-1}+X_{i}^{\prime} \gamma+\varepsilon_{i},
\end{aligned}
$$

where $\ln y_{i}$ is the natural $\log$ of the average number of unemployment benefit II recipients finding a job each month. The indicator variable $I_{i}$ takes a value of one if unemployment benefit II recipients are cared for by an ALP in region $i$ and a value of zero otherwise.

Following the empirical literature estimating matching functions (for Germany compare Gross 1997; Entorf 1998; Fahr and Sunde 2005) which bases its estimation equation for transition rates on the theoretical idea of a labour market matching function we include the stocks of unemployment benefit I and benefit II recipients searching for a job and the number of newly available vacancies. Since labour markets exceed administrative boundaries of single regions we include not only the stock of unemployment benefit I and benefit II recipients and the number of newly available vacancies in region $i$ but also in the respective neighbouring

\footnotetext{
${ }^{7}$ This pattern also holds in the preceding period, e.g. the transition rates are $3,10 \%$ for JLAs and 3,30 \% for ALPs in September 2006. This descriptive statistics suggest that the treatment effect in 2006 goes in the same direction as in 2007, the period analysed in the paper.
}

regions $n i$ within a distance of $100 \mathrm{~km}$. The neighbouring regions are weighted inversely to their distance to the region under consideration. $X_{i}$ is a vector of variables controlling for regional characteristics like urbanisation, State-fixed effects, and the natural $\log$ of population size in region $i$.

The OLS estimate of the indicator variable $I_{i}$ in the upper part of Table 4 shows a negative correlation between regions with ALPs and the unemployment to employment transition rate of unemployment benefit II recipients. Although the OLS estimates for the indicator variable $I_{i}$ indicate a negative relationship between ALPs and the job finding rate, it remains unclear whether being cared for by an ALP has a causal negative impact on the job finding rate. In fact, OLS estimation is only able to identify the effect of being an ALP on the job finding rate if the error term $\varepsilon_{i}$ exhibits no spatial autocorrelation and has a zero mean conditional on all covariates. $^{8}$

We cluster the observations at the state level to control for spatial autocorrelation. Clustering on the state level allows for any correlation within each state. The test for spatial autocorrelation based on Moran's I shown in Table 4 indicates that no spatial autocorrelation is present, if spatial autocorrelation is assumed to depend on distance, i.e., on a weighting matrix, where the neighbouring regions within $100 \mathrm{~km}$ are weighted inversely to their distance to the region under consideration. ${ }^{9}$

To overcome the potential bias of the indicator variable $I_{i}$ on $\ln y_{i}$ we use an instrumental variable approach. As an instrument we use a variable that indicates whether the mayor of a region was a board member or a State president of the German County Association ("Deutscher Landkreistag") in 2004, the year when regions had to apply to become an ALP. The German County Association ${ }^{10}$ is the federal association of German rural regions and its main tasks are to promote local government self-administration (which is guaranteed by the German Constitution) and to foster common interests between all regional government bodies vis-à-vis the Federal State and the German States. It is financed through small contributions made by all rural regions. As a lobbying institution, it tries to influence Federal and State level legislation that affects regions in the interest of all rural regions. The

\footnotetext{
${ }^{8}$ The estimates are based on the period January to July 2007 and they therefore only apply to this period. If ALPs or JLAs have improved their performance in the years after 2007 at different speeds, then the treatment effect in the years after 2007 might differ from the one presented here.

${ }^{9}$ Table A.2 in the Appendix displays all OLS-regressions and the Moran's I tests for all specifications of IV-regressions used in this paper. All these tests indicate that controlling for spatial autocorrelation by clustering on the state level is sufficient to overcome potential spatial autocorrelation. Hence, we cluster the observations in the IVregressions on the state level.

${ }^{10}$ For more information (in German) see: http://www.kreise. de/_cms1/dlt-portrait.html.
} 
German County Association exerts its main influence on regions by providing information to regional governments through its journal "Der Landkreis" or by providing rural regions a platform to exchange their experience on certain issues. The platforms where rural regions could discuss their experience in caring for unemployment benefit II recipients were open to all rural regions irrespective of whether the region cared for the unemployment benefit II recipients in an ALP or a JLA institution. Furthermore, it is worth noting that the German County Association has no financial means to influence local public policy via subsidies or alike. Thus, the German County Association could only influence the local labour market policy indirectly through the provision of information. For the validity of our instrument it is important that this information was made available to all regions irrespective of whether they cared for unemployment benefit II recipients in an ALP or a JLA institution.

The German County Association feared that regions in charge of the local social benefit administration would lose autonomy in budgetary and personnel matters if they gave up the important task of caring for unemployment benefit II recipients by merging with the local public employment services that are accountable to the Federal Employment Agency. It therefore campaigned for giving regions the sole responsibility for the care of unemployment benefit II recipients, i.e., they campaigned for having the ALP institutions implemented nationwide. Given the enormous task of caring for all unemployment benefit II recipients and the political responsibilities associated with such a challenge, not all local governments shared the view of the German County Association that it is preferable to be solely responsible for unemployment benefit II recipients. Especially the mayors on the board of the German County Association and those who were State presidents of the German County Association pushed their regions to apply. Eight out of nineteen regions where a mayor was a board member or a federal state president of the German County Association applied to become an ALP. As shown by the first stage regression in Table A.4 in the Appendix, the fact that the mayor of a region was a board member of the German County Association or a State president in 2004 increased the probability that the region applied to become an ALP. The coefficient of the German County Association variable is positive and highly significant. The F-statistics for the significance of the German County Association indicator variable in the first stage regression are between 7.92 and 13.72 for the different specification used throughout this paper (see Table A.3 in the Appendix). The F-statistics, therefore, support the hypothesis that the mayors on the board of the German County Association had an important influence on whether a region applied for becoming an ALP.

The German County Association indicator variable would not be a valid instrument to control for positive self-selection if the mayors on the board of the German County Association were elected based on their labour market performance. The board of the German County Association is elected every two years and the federal state presidents of the German County Association every two to three years. ${ }^{11}$ Using data for the years 2001 until 2003 we can investigate whether labour market variables are positively correlated with being a board member or a federal state president of the German County Association in 2004, the year when regions had to apply to become ALPs. Since by definition only rural regions are members of the German County Association the sample for the descriptive statistics in Table 3 is restricted to rural regions only to investigate whether the mayors on the board of the German County Association are from rural regions with better labour market conditions than other rural regions. ${ }^{12}$ The fact that the rural regions with a mayor that is a board member or a federal state president of the German County Association have similar unemployment rates, similar long-term unemployment rates and similar unemployment assistance and social assistance recipient rates compared to other rural regions suggests that regions with a mayor that is a board member or a federal state president of the German County Association are not associated with better labour market conditions. This supports the validity of our instrument.

The IV estimate and the OLS estimate of the overall treatment effect of being an ALP are shown in Table 4. The magnitude of the coefficients suggests that the number of unemployment benefit II recipients that find a job is $2 \%$ lower in regions with ALPs. ${ }^{13}$ The coefficients of all variables are shown in column 1 of Table A. 2 and Table A. 3 in the Appendix. The IV estimate of being an ALP is not significantly different from zero. The IV estimate in Table 4 for the treatment effect of being an ALP is almost identical to the OLS estimates. The Durbin-Wu Hausman Test reported in Table 4 supports the observation that the OLS estimate and the IV estimate are not significantly different from each other.

\footnotetext{
${ }^{11}$ See Paragraph 7 of the articles of the German County Association, i.e. http://www.kreise.de/landkreistag/dlt-satzung-2005.pdf, and the articles of the State Associations of German Counties.

${ }^{12}$ Urban and metropolitan regions are members of the German City Association (Deutscher Städtetag). Including urban or metropolitan regions into the sample would imply that we include regions into the sample that by definition cannot be part of the German County Association.

${ }^{13}$ Boockmann et al. (2010) find a negative effect of ALP on the employment rate of men without in-work benefits and no significant effects otherwise. These results suggest that the transition rate from unemployment into employment (without welfare receipt) is $24 \%$ lower in ALPs (see page 14 in Boockmann et al. 2010). Our estimates of the treatment effect of ALPs based on the transition rate as dependent variable range between $0.5 \%$ to $1.4 \%$ (see Table A.5). Thus, they are 20 times smaller.
} 
Table 3 Labour market conditions in rural regions in 2001-2003 (weighted averages)

\begin{tabular}{|c|c|c|c|}
\hline & 2001 & 2002 & 2003 \\
\hline \multicolumn{4}{|c|}{ Unemployment to employment transition rate ${ }^{\mathrm{a}}$ (weighted by the number of unemployed per region) } \\
\hline German County Association & $6.83[5.91 ; 7.75]$ & $6.50[5.69 ; 7.31]$ & $6.51[5.79 ; 7.22]$ \\
\hline Other rural regions & $7.43[7.17 ; 7.68]$ & $6.97[6.75 ; 7.19]$ & $6.93[6.72 ; 7.14]$ \\
\hline \multicolumn{4}{|c|}{ Unemployment rate (weighted by the number of unemployed per region) } \\
\hline German County Association & $8.98[6.48 ; 11.49]$ & $9.31[6.88 ; 11.75]$ & $10.09[7.55 ; 12.63]$ \\
\hline Other rural regions & $8.70[8.11 ; 9.39]$ & $9.07[8.49 ; 9.65]$ & $9.71[9.13 ; 10.30]$ \\
\hline \multicolumn{4}{|c|}{ Long-term unemployment rate (weighted by the number of unemployed per region) } \\
\hline German County Association & $3.05[2.10 ; 4.01]$ & $3.05[2.03 ; 4.06]$ & $3.44[2.26 ; 4.63]$ \\
\hline Other rural regions & $2.93[2.70 ; 3.16]$ & $2.96[2.71 ; 3.22]$ & $3.29[3.00 ; 3.58]$ \\
\hline \multicolumn{4}{|c|}{ Unemployment assistance recipient rate ${ }^{\mathrm{a}}$ (weighted by the working age population per region) } \\
\hline German County Association & $2.60[1.49 ; 3.72]$ & $2.98[1.72 ; 4.24]$ & $3.56[2.10 ; 5.02]$ \\
\hline Other rural regions & $2.52[2.25 ; 2.79]$ & $2.90[2.60 ; 3.21]$ & $3.46[3.12 ; 3.81]$ \\
\hline \multicolumn{4}{|c|}{ Social assistance recipient rate ${ }^{\mathrm{a}}$ (weighted by the working age population per region) } \\
\hline German County Association & $3.46[2.87 ; 4.06]$ & $3.73[3.10 ; 4.37]$ & $3.78[3.14 ; 4.42]$ \\
\hline Other rural regions & $3.66[3.48 ; 3.83]$ & $3.78[3.60 ; 3.96]$ & $3.91[3.72 ; 4.10]$ \\
\hline
\end{tabular}

a The unemployment and social assistance rate are weighted in percent of working age population (18 to 64 year olds). Unemployment assistance recipients are weighted similarly. Source: Own calculations based on data from the Federal Employment Office

Confidence intervals with $*$ and $* *$ indicate significance at a $5 \%$ and $1 \%$ level, respectively

Table 4 Relationship between ALPs and the number of unemployment benefits II recipients finding a job each month

\begin{tabular}{ll}
\hline Dependent variable & $\begin{array}{l}\text { Log number of benefit II } \\
\text { recipients finding a job } \\
\text { each month }\end{array}$ \\
\hline
\end{tabular}

\section{OLS estimates}

Approved Local Providers

$-0.018$

[0.084]

Observations

409

Moran's I

0.863

$p$-Value (Moran's I)

0.388

$R$-Squared

0.973

IV estimates

Approved Local Providers

$-0.018$

[0.084]

Observations

409

$F$-Statistic

8.02

Durbin-Wu-Hausman Test ( $p$-Value)

0.988

$R$-Squared

0.973

Standard errors are given in parentheses. Observations are clustered at the level of the 16 German states and weighted by the number of unemployment benefit II recipients in each region

Confidence intervals with $*$ and $* *$ indicate significance at a $5 \%$ and $1 \%$ level, respectively

\section{The role of organisational characteristics}

Why did regions self-select into being solely responsible for the unemployment benefit II recipients given that the OLSestimates and the IV-estimates indicate that ALPs are not better than JLAs in integrating the unemployment benefit II recipients into the labour market. Clearly, the local governments that applied for becoming ALPs must have thought that they are better able to care for the unemployment benefit II recipients if they do not merge with the local public employment service. Being an ALP allows the local government to design the organisation and activation process for the unemployment benefit II recipients according to their own agenda. Being a JLA, however, limits the local authorities' scope to shape the organisational structure, because local governments and the Federal Employment Agency had to agree on the organisational characteristics of the local job centre. This restriction might have induced local governments that believed that they could better organise the activation process of unemployment benefit II recipients on their own to apply to become ALP. The unique dataset on organisational characteristics allows us to investigate this hypothesis and to shed some light on the factors that determine a successful institution.

Table 5 shows some organisational characteristics used by job centres. Many organisational characteristics are not unique to one of the two institutions, but can be found in 
either ALPs or JLAs. Even though the Federal Employment Agency had to agree with the organisation implemented by JLAs, JLAs were still able to implement different organisational structures as the considerable diversity of the organisational characteristics in JLAs in Table 5 shows.

We examine the role of these organisational characteristics by including sets of organisational variables step by step into our IV regression. Table 6 presents the estimates of the organisational variables based on our standard estimation equation given in (1). The OLS regression results, which are very similar to the IV regression results, are given in Table A.2 in the Appendix.

Table 5 Organisational characteristics of job centres

\begin{tabular}{lll}
\hline & $\begin{array}{l}\text { Approved Local } \\
\text { Providers }\end{array}$ & $\begin{array}{l}\text { Joint Local } \\
\text { Agencies }\end{array}$ \\
\hline $\begin{array}{l}\text { Specialised case } \\
\text { management }\end{array}$ & $75.8 \%$ & $24.6 \%$ \\
$\begin{array}{l}\text { Generalised case } \\
\text { management }\end{array}$ & $24.2 \%$ & $75.4 \%$ \\
$\begin{array}{l}\text { Own vacancy recruitment } \\
\text { service }\end{array}$ & $91.1 \%$ & $16.6 \%$ \\
$\begin{array}{l}\text { Integrated matching } \\
\text { approach }\end{array}$ & $14.3 \%$ & $6.7 \%$ \\
$\begin{array}{l}\text { Length of first interview } \\
\text { (in minutes) }\end{array}$ & $51 \mathrm{~min}$ & $48 \mathrm{~min}$ \\
$\begin{array}{l}\text { First interview within } 2 \\
\text { weeks }\end{array}$ & $71.1 \%$ & $46.6 \%$ \\
Agreement signed & $73.0 \%$ & $74.1 \%$ \\
\hline
\end{tabular}

Source: Own calculations based on the survey IAW-SGBII-Organisationserhebung
First, we include in column 2 a dummy variable for regions that use a specialised case management approach. An organisation is characterised as having a specialised case management approach if unemployment benefit II recipients are profiled according to their labour market chances and those in need for support are counselled by special case managers. As shown in Table 5, 75.8 \% of JLAs and $24.6 \%$ of ALPs use a specialised case management approach. The remaining $24.2 \%$ of JLAs and $75.4 \%$ of ALPs use a generalised case management, where all unemployment benefit II recipients are coached equally and independently of their profiling outcome. The coefficient for the specialised case management approach in column 2 shows a negative correlation between the specialised case management approach and the number of unemployment benefit II recipients finding a job. The magnitude of the coefficients suggests that the number of unemployment benefit II recipients that find a job is 2 to $3 \%$ lower in job centres with a specialised case management approach. In addition, the coefficient for the indicator variable for regions with ALPs becomes even more negative. This pattern suggests that ALPs have primarily chosen the more successful generalised case management approach.

In column 3 we include two dummy variables that characterise how vacancies are recruited and how well the matching process of unemployment benefit II recipients to job vacancies is integrated into the case management approach. The first dummy variable indicates whether or not a job centre has its own vacancy recruitment service. As shown in Table 5, $16.6 \%$ of JLAs and $91.1 \%$ of ALPs have their own vacancy recruitment service. Job centres without their own vacancy recruitment service use the vacancy recruitment service of the local public employment service

Table 6 IV estimates of the relationship of ALPs and the number of unemployment benefit II recipients finding a job

\begin{tabular}{llccc}
\hline Dependent variable & \multicolumn{4}{l}{ Log number of benefit II recipients finding a job each month } \\
\cline { 2 - 5 } & $(1)$ & $(2)$ & $(3)$ & $(4)$ \\
\hline Approved Local Provider & $-0.018[0.084]$ & $-0.031[0.102]$ & $-0.058[0.137]$ & $-0.087[0.140]$ \\
Specialised case management & & $-0.019[0.025]$ & $-0.022[0.025]$ & $-0.029[0.027]$ \\
Own vacancy recruitment service & & & $0.011[0.052]$ & $0.023[0.054]$ \\
Integrated matching approach & & & $0.039[0.020]$ & $0.043[0.025]$ \\
Length of first interview (Log) & & & $0.023[0.018]$ \\
First interview within 2 weeks & & & $0.027[0.031]$ \\
Agreement signed & 409 & 399 & 399 & $0.010[0.025]$ \\
Observations & 8.02 & 7.92 & 12.01 & 387 \\
$F$-Statistic & 0.988 & 0.998 & 0.865 & 13.72 \\
Durbin-Wu-Hausman Test ( $p$-value) & 0.973 & 0.973 & 0.973 & 0.635 \\
$R$-Squared & & & 0.973 \\
\hline
\end{tabular}

Standard errors are given in parentheses. Observations are clustered at the level of the 16 German states and weighted by the number of unemployment benefit II recipients in each region. The variables of neighbouring regions are constructed such that regions within $100 \mathrm{~km}$ are weighted inversely to their distance to the region under consideration

Confidence intervals with $*$ and $* *$ indicate significance at a $5 \%$ and $1 \%$ level, respectively 
that is still responsible for unemployment benefit I recipients. Although the positive correlation between the existence of an own vacancy recruitment service and the job finding rate of unemployment benefit II recipients is not statistically significant, it still suggests that unemployment benefit II recipients that use the vacancy recruitment service of the local public employment service face in-house competition of unemployment benefit I recipients. The number of unemployment benefit II recipients finding a job is according to the respective coefficient 1 to $2 \%$ lower. Again, the fact that ALPs have primarily chosen the better performing institutional setting can explain why they did not want to be merged with the local public employment service, where they had less influence in shaping the organisational structure according to their own agenda.

The second dummy variable characterises how well the matching of unemployment benefit II recipients to vacancies is integrated into the case management approach. It is one if the vacancy recruitment services generally communicate new vacancies to case managers responsible for the unemployment benefit II recipients, and zero if the vacancy recruitment service primarily matches unemployment benefit II recipients and job vacancies on its own without consulting the case managers. The integrated approach seems to be positively correlated (although not statistically significant) with the job finding rate and is adopted by $14.3 \%$ of regions with ALP and by $6.7 \%$ of regions with JLAs. The estimates-although not significantly different from zerosuggest that an integrated matching approach increases the number of unemployment benefit II recipients finding a job by around $4 \%$.

In column 4 we include three variables that characterise the intensity and speed with which unemployment benefit II recipients are activated; the length of the first interview, the fraction of new entrants into the unemployment benefit II system that have had their first interview within two weeks after filing their application, and the fraction of unemployment benefit II recipients that signed an agreement (Eingliederungsvereinbarung) with the job centre. These agreements define the search requirements and training obligations of unemployment benefit II recipients. If unemployment benefit II recipients do not comply with these obligations, they can be sanctioned. The fraction of unemployment benefit II recipients that signed an agreement is on average $73.0 \%$ in regions with ALPs and $74.1 \%$ in regions with JLAs. In regions with JLAs, $71.1 \%$ of new entrants into the unemployment benefit II system had their first interview within two weeks, in regions with ALPs only $46.6 \%$. While JLAs seem to activate faster, ALPs take more time to talk to the unemployment benefit II recipients. In job centres in regions with ALPs the first interview lasted on average 51 minutes, while in job centres in regions with JLAs it lasted only 48 minutes. All three variables are not significantly different from zero.
The fact that organisational characteristics like the generalised case management approach and the integration of the vacancy recruitment service chosen by the ALPs are positively correlated with the job finding rate of unemployment benefit II recipients and the fact that the indicator variable for ALPs becomes more negative as more organisational variables are added indicates again that ALPs have chosen the better organisational structure.

From a policy perspective our analysis suggests two things. Firstly, local public employment services and local social benefit administrations should be merged in order to ensure a better one-stop-shop organisation for unemployment benefit II recipients and to increase the transition rates from unemployment to employment. Secondly, the job centres should implement a generalised case management approach that compared to a specialised case management approach treats all unemployment benefit II recipients with equal intensity and does not leave some unemployment benefit II recipients uncounselled or unmonitored. Furthermore, job centres should not rely on the vacancy recruitment service of the local public employment service but should instead build up their own vacancy recruitment service in order to avoid that unemployment benefit II recipients have to compete with unemployment benefit I recipients. In addition, the recruited vacancies should be passed on to the contact persons of the unemployment benefit II recipients in order to improve the matching of unemployed workers to vacant jobs.

\section{Conclusions}

Using a policy experiment in Germany we find that merging local public employment services and social benefit administrations has the potential to improve the job finding probability of unemployment benefit II recipients. Furthermore, the fact that the organisational features implemented primarily by ALPs are positively correlated with the job finding probability of unemployment benefit II recipients indicates that local governments that self-selected into ALPs seem to have implemented a better organisational structure. However, the relatively poor performance of ALPs compared to JLAs suggests that ALPs did underestimate the positive effect that a merger between the local public employment service and the local social benefit administration has on the job finding rate of unemployment benefit II recipients.

\section{Executive summary}

The aim to simultaneously enhance both flexibility and security in the labour market has led the European Commission together with the Member States to develop a set of 
common principles for flexicurity. The principle to provide social assistance recipients with the means necessary to find a job and to achieve an acceptable living standard requires a higher degree of cooperation between local public employment services and social benefit administrations. Some European countries have decentralised their public employment services to increase the cooperation with social benefit administrations at the local level, others have merged public employment services and social benefit administrations (European Commission 2006). In Germany in 2005 a policy experiment came into effect with the aim to evaluate whether merging public employment services and social benefit administrations improves the job finding probability of unemployment benefit II recipients.

Before the Hartz IV reform, Germany had two separate institutions; the local social benefit administrations, which cared for social assistance recipients, and the local public employment services, which cared for unemployment assistance recipients. Under Hartz IV these institutions where merged and persons belonging to one of the two groups were now named unemployment benefit II recipients. The predominate organisational form, which cares for unemployment benefit II recipients is called Joint Local Agency (JLA), since it constitutes a joint venture between the local public employment service and the local social benefit administration. Due to the experiment, 69 out of 442 regions created new institutions named Approved Local Providers (ALP) by enlarging the former local social benefit administrations.

In an attempt to identify the better institution the performance of JLAs was compared with the performance of ALPs after the Hartz IV reform. We use an instrumental variable approach to control for potential self-selection into the treatment "Approved Local Provider". As an instrument we use information about the involvement of local political representatives in the German County Association ("Deutscher Landkreistag"). The German County Association is a political lobbying institution that promoted the introduction of ALPs in all German regions and that had a large influence on which regions applied for becoming an ALP, but has no influence on the regional labour market performance.

The OLS-estimate and the IV-estimate for the treatment effect of being an ALP (without controlling for organisational characteristics) are insignificant, but they indicate that unemployment benefit II recipients in regions with ALPs have lower unemployment to employment transition rates than unemployment benefit II recipients in regions with JLAs. We also find that regions that later became ALPs had slightly better labour market conditions before the Hartz IV reform. Thus, despite the evidence that local governments in regions with better labour market conditions prior to the Hartz IV reform selected themselves into being ALPs, regions with ALPs do not perform better than JLAs.
To gain further insight into the organisational features that determine the success of an institution, we are able to use a unique dataset on the major organisational characteristics of all job centres. Many organisational features are not unique to one of the two institutions, but can be found in either ALPs or JLAs. Thus, our dataset allows us to shed some light on the factors that determine a successful institution. We find that unemployment benefit II recipients in regions where job centres use a generalised case management approach have a higher job finding probability compared to unemployment benefit II recipients in regions where job centres use a specialised case management approach. ALPs predominantly use the more successful generalised case management approach while JLAs primarily use a specialised case management approach. Moreover, ALPs mostly have their own vacancy recruitment service while JLAs frequently use the vacancy recruitment service of the local public employment service that is also responsible for unemployment benefit I recipients. In addition, ALPs more often use an integrated matching approach, where the vacancy recruitment service generally communicates new vacancies to case managers and does not primarily match unemployment benefit II recipients and job vacancies on its own. Both measures that are primarily used by ALPs are positively correlated with higher job finding rates.

The fact that Approved Local Providers predominantly implemented an organisational structure that is positively correlated with the job finding probability of unemployment benefit II recipients indicates that regions that selfselected into ALPs seem to have implemented an organisational structure that is better suited to integrate unemployment benefit II recipients into the labour market. However, the relatively poor performance of ALPs compared to JLAs-as shown by the treatment effect after controlling for organisational characteristics-indicates that having a better organisational structure does not compensate for the lost benefits of having the local public employment service and local social benefit administration integrated.

\section{Kurzfassung}

Die EU versucht mit ihrem neuen beschäftigungspolitischen Leitbild „Flexicurity“ zwei scheinbar unvereinbare Anforderungen nämlich Flexibilität und Sicherheit auf den Arbeitsmärkten miteinander in Einklang zu bringen. Dieses Konzept hatte in Deutschland unter anderem zur Konsequenz, dass lokale Arbeitsagenturen und die Sozialverwaltung enger kooperieren mussten, um Sozialhilfeempfänger und Arbeitssuchende mit allen notwendigen Mitteln ausstatten zu können, die sie zur Arbeitsplatzsuche und zur sozialen Stabilisierung benötigten. In Deutschland hat man sich im Jahr 2005 daher für ein Politikexperiment entschieden. 
Ziel des Experimentes war es zu evaluieren, ob eine institutionelle Zusammenführung oder eine Kooperation von Arbeits- und Sozialverwaltung die bessere Wahl zur Integration von Arbeitssuchenden aus dem Rechtskreis SGB II in den Arbeitsmarkt darstellt. Daher existieren seit dem 1. Januar 2005 unterschiedliche Modelle der Betreuung erwerbsfähiger Hilfebedürftiger (sogenannte Hartz IV Empfänger): Arbeitsgemeinschaften (ARGEn) von Arbeitsagenturen und Kommunen (Kooperation) und zugelassene kommunale Trägern (zkT) (institutionelle Selbstständigkeit kommunaler Träger).

Vor Einführung der Hartz IV Reform, existierten in Deutschland zwei voneinander getrennte Institutionen; die kommunale Sozialverwaltung, die sich um Sozialhilfeempfänger kümmerte, und die Arbeitsämter, die für Arbeitslosenhilfeempfänger zuständig waren. Mit dem In-KraftTreten der Hartz IV Reform, mussten diese beiden Institutionen deutlich enger zusammenarbeiten, da sie mit unterschiedlichen Aufgabenschwerpunkten jetzt gemeinsam sowohl für erwerbsfähige Arbeitslosen- als auch Sozialhilfeempfänger - sogenannte Arbeitslosengeld II-Empfänger verantwortlich waren. Die vorherrschende organisatorische Form der Betreuung arbeitsfähiger Hilfebedürftiger ist das sogenannte ARGE-Modell. Insgesamt 69 von insgesamt 442 Regionen haben sich hingegen für das sogenannte zkTModell entschieden.

Im Rahmen der Studie wurde untersucht, ob diejenigen regionalen Einheiten, die als zugelassene kommunale Träger agieren, aufgrund ihrer Wahl dieser Form der Aufgabenwahrnehmung erfolgreicher bei der Vermittlung erwerbsfähiger Arbeitslosengeld II Empfänger sind, oder ob dies umgekehrt für ARGEn aufgrund ihrer Form der Trägerschaft gilt.

Zur Berücksichtigung des möglichen Selektionsproblems bei der Wahl der Form der Aufgabenwahrnehmung wurde ein Instrumentvariablenansatz gewählt. Als Instrumentvariable diente die Information, ob der Landrat im Präsidium des Deutschen Landkreistages bzw. als Präsident eines Landesverbandes des Landkreistages tätig ist. Der Deutsche Landkreistag sprach sich in den politischen Diskussionen vor 2004 für die zkT aus, da er fürchtete, dass bei einer Übertragung der Verantwortung für die Betreuung von Arbeitslosengeld II-Beziehern auf die Bundesagentur für Arbeit die Kommunen einen Großteil der Verantwortung, die sie bei der Betreuung von Sozialhilfeempfängern und -empfängerinnen inne hatten, verlieren, während sie mit der zugelassenen kommunalen Trägerschaft hingegen an Verantwortung gewinnen würden. Der Deutsche Landkreistag hatte einen starken Einfluss darauf, welche Regionen sich als zkTs beworben haben, ohne jedoch Einfluss auf die regionale Arbeitsmarktperformance zu haben.

Die OLS- als auch die IV-Schätzer des TreatmentEffektes eines zugelassenen kommunalen Trägers (ohne
Kontrolle von organisatorischen Merkmalen) sind zwar nicht signifikant, deuten aber darauf hin, dass in zkTRegionen im Vergleich zu ARGEn-Regionen Arbeitslosengeld II-Empfänger niedrigere Übergangsraten in die Erwerbstätigkeit aufweisen. Des Weiteren zeigen die Ergebnisse, dass Regionen, die sich nach der Hartz IV Reform für das zkT Modell entschieden im Vorfeld geringfügig bessere Arbeitsmarktbedingungen hatten. Das heißt, obwohl sich die regionalen Verantwortungsträger von Regionen mit günstigeren Arbeitsmarktbedingungen für das Modell der zkT entschieden haben, ist die Arbeitsmarktintegration in zkTRegionen nicht erfolgreicher als in ARGEn-Regionen.

Um einen tieferen Einblick in die organisatorische Struktur der relevanten Institutionen zu gewinnen, die den Erfolg dieser maßgeblich beeinflussen kann, wurde ein spezifischer Datensatz genutzt, der wichtige Merkmale aller Arbeitsagenturen enthält. Viele Organisationsmerkmale finden sich in nicht ausschließlich in zkT- oder ARGEn-Regionen, vielmehr sind sie in beiden Institutionsformen verbreitet. Deshalb ermöglicht es der verwendete Datensatz, etwas Licht in das Dunkel erfolgreicher Institution zu bringen. Arbeitslosengeld II-Empfänger in Regionen, die einen generalisierten Fallmanagementansatz anwenden, haben eine höhere Wahrscheinlichkeit eine Erwerbstätigkeit aufzunehmen als solche in Regionen, die einen spezialisierten Fallmanagementansatz verfolgen. Darüber hinaus ließ sich zeigen, dass zkT-Regionen häufig eine eigene Arbeitsplatzvermittlungsstelle für Arbeitslosengeld II-Empfänger unterhielten, wohingegen ARGEn überwiegend gemeinsame Arbeitsplatzvermittlungsstellen für Arbeitslosengeld I- und Arbeitslosengeld II-Empfänger aufwiesen. Des Weiteren praktizieren zkTs häufig einen integrierten Vermittlungsansatz, d.h. offene Stellen werden generell den Fallmanagern kommuniziert, es erfolgt jedoch kein expliziter Abgleich von Arbeitslosengeld II-Empfängern und offenen Stellen. Beide Vorgehensweisen, die insbesondere bei zkTs praktiziert werden, sind jedoch positiv korreliert mit einer höheren Erfolgsquote der Erwerbstätigkeitsaufnahme.

Die Tatsache, dass zkT-Regionen überwiegend Organisationsstrukturen verwenden, die positiv korreliert sind mit den höheren Erfolgsquoten beim Übergang in die Erwerbstätigkeit von Arbeitslosengeld II-Empfängern, deutet darauf hin, dass diese Regionen, die sich in das zkT Modell selektiert haben, die für die Arbeitslosengeld II-Empfänger erfolgreichere Organisationsform gefunden haben. Allerdings bedeutet die relativ schlechte Performance der zkTRegionen im Vergleich zu den ARGEn-Regionen - wie auf Basis des Treatment-Effekts unter Kontrolle der Organisationsmerkmale gezeigt wurde -, dass auch die bessere Organisationsform nicht die Nachteile kompensieren kann, die sich aus der integrierten Form der kommunalen Arbeitsvermittlung und der Sozialverwaltung ergeben haben. 
Acknowledgements The authors wish to thank Stefan Bauernschuster, Thiess Büttner, Michael Fertig and Martin Werding for their useful comments, and Rolf Kleimann for invaluable assistance with the data. The usual disclaimer applies.
Appendix: Tables A.1, A.2, A.3, A.4, A.5

Table A.1 Descriptive statistics

\begin{tabular}{|c|c|c|c|}
\hline & Approved Local Providers & Joint Local Agencies & All job centres \\
\hline Job centres ( $=$ number of regions) & 69 & 353 & 442 \\
\hline Sample (= number of regions) & 56 & 353 & 409 \\
\hline Job finding rate & $3.83 \%$ & $3.98 \%$ & $3.96 \%$ \\
\hline Job finding rate in rural regions & $3.83 \%$ & $4.21 \%$ & $4.15 \%$ \\
\hline Specialised case management & $75.8 \%$ & $24.6 \%$ & $67.9 \%$ \\
\hline Generalised case management & $24.2 \%$ & $75.4 \%$ & $32.1 \%$ \\
\hline Own vacancy recruitment service & $91.1 \%$ & $16.6 \%$ & $27.1 \%$ \\
\hline Integrated matching approach & $14.3 \%$ & $6.7 \%$ & $7.77 \%$ \\
\hline Length of first interview (in minutes) & $51 \mathrm{~min}$ & $48 \min$ & $49 \min$ \\
\hline First interview within 2 weeks & $71.1 \%$ & $46.6 \%$ & $67.5 \%$ \\
\hline Agreement signed & $73.0 \%$ & $74.1 \%$ & $73.9 \%$ \\
\hline Unemployment benefit II recipients finding a job each month & 241 & 296 & 288 \\
\hline Unemployment benefit II recipients & 6,609 & 8,540 & 8,276 \\
\hline Unemployment benefit II recipients in neighbouring regions (weighted) & 5,180 & 7,210 & 6,940 \\
\hline Short-term unemployed & 3,474 & 3,610 & 3,592 \\
\hline Short-term unemployed in neighbouring regions & 2,287 & 3,108 & 2,996 \\
\hline New vacancies & 357 & 607 & 572 \\
\hline New vacancies in neighbouring regions & 376 & 502 & 484 \\
\hline Rural regions & $91.1 \%$ & $68.3 \%$ & $71.4 \%$ \\
\hline Metropolitan regions & $1.8 \%$ & $10.8 \%$ & $9.5 \%$ \\
\hline Population & 173,584 & 187,636 & 185,712 \\
\hline
\end{tabular}

The variables of neighbouring regions are constructed such that regions within $100 \mathrm{~km}$ are weighted inversely to their distance to the region under consideration 
Table A.2 OLS-Estimates

\begin{tabular}{|c|c|c|c|c|}
\hline \multirow[t]{2}{*}{ Dependent variable } & \multicolumn{4}{|c|}{ Log number of benefit II recipients finding a job each month } \\
\hline & (1) & $(2)$ & (3) & (4) \\
\hline Approved Local Provider & $-0.018[0.084]$ & $-0.031[0.102]$ & $-0.058[0.137]$ & $-0.087[0.140]$ \\
\hline Specialised case management & & $-0.019[0.025]$ & $-0.022[0.025]$ & $-0.029[0.027]$ \\
\hline Own vacancy recruitment service & & & $0.011[0.052]$ & $0.023[0.054]$ \\
\hline Integrated matching approach & & & $0.039[0.020]$ & $0.043[0.025]$ \\
\hline Length of first interview (Log) & & & & $0.023[0.018]$ \\
\hline First interview within 2 weeks & & & & $0.027[0.031]$ \\
\hline Agreement signed & & & & $0.010[0.025]$ \\
\hline $\begin{array}{l}\text { Unemployment benefit II } \\
\text { recipients (Log) }\end{array}$ & $0.774 * *[0.059]$ & $0.767 * *[0.061]$ & $0.762 * *[0.067]$ & $0.760 * *[0.072]$ \\
\hline $\begin{array}{l}\text { Unemployment benefit II } \\
\text { recipients in neighbouring } \\
\text { regions (Log) }\end{array}$ & $-0.137[0.071]$ & $-0.132[0.075]$ & $-0.128[0.076]$ & $-0.135[0.074]$ \\
\hline Short-term unemployed (Log) & $-0.024[0.072]$ & $-0.018[0.070]$ & $-0.017[0.068]$ & $-0.025[0.076]$ \\
\hline $\begin{array}{l}\text { Short-term unemployed in } \\
\text { neighbouring regions ( } \log )\end{array}$ & $0.036[0.084]$ & $0.035[0.083]$ & $0.038[0.084]$ & $0.061[0.090]$ \\
\hline New vacancies (Log) & $0.047[0.028]$ & $0.046[0.028]$ & $0.044[0.026]$ & $0.035[0.025]$ \\
\hline $\begin{array}{l}\text { New vacancies in neighbouring } \\
\text { regions (Log) }\end{array}$ & $0.082[0.070]$ & $0.079[0.072]$ & $0.071[0.072]$ & $0.055[0.074]$ \\
\hline Rural regions & $0.026[0.021]$ & $0.020[0.026]$ & $0.020[0.025]$ & $0.018[0.025]$ \\
\hline Metropolitan regions & $-0.034[0.033]$ & $-0.044[0.032]$ & $-0.046[0.031]$ & $-0.050[0.030]$ \\
\hline Population (Log) & $0.170[0.087]$ & $0.171[0.084]$ & $0.174[0.093]$ & $0.194 *[0.090]$ \\
\hline Constant & $-2.931 * *[0.544]$ & $-2.925 * *[0.510]$ & $-2.935 * *[0.527]$ & $-3.176 * *[0.479]$ \\
\hline Observations & 409 & 399 & 399 & 387 \\
\hline Moran's I & 0.863 & 0.870 & 0.886 & 0.874 \\
\hline$p$-Value (Moran's I) & 0.388 & 0.384 & 0.376 & 0.382 \\
\hline$R$-Squared & 0.973 & 0.973 & 0.973 & 0.973 \\
\hline
\end{tabular}

Standard errors are given in parentheses

Confidence intervals with $*$ and $* *$ indicate significance at a $5 \%$ and $1 \%$ level, respectively. Observations are clustered at the level of the 16 German states and weighted by the number of unemployment benefit II recipients in each region. The variables of neighbouring regions are constructed such that regions within $100 \mathrm{~km}$ are weighted inversely to their distance to the region under consideration 
Table A.3 IV-Estimates (Second stage)

\begin{tabular}{|c|c|c|c|c|}
\hline \multirow[t]{2}{*}{ Dependent variable } & \multicolumn{4}{|c|}{ Log number of benefit II recipients finding a job each month } \\
\hline & $(1)$ & $(2)$ & (3) & (4) \\
\hline Approved Local Provider & $-0.018[0.084]$ & $-0.031[0.102]$ & $-0.058[0.137]$ & $-0.087[0.140]$ \\
\hline Specialised case management & & $-0.019[0.025]$ & $-0.022[0.025]$ & $-0.029[0.027]$ \\
\hline Own vacancy recruitment service & & & $0.011[0.052]$ & $0.023[0.054]$ \\
\hline Integrated matching approach & & & $0.039[0.020]$ & $0.043[0.025]$ \\
\hline Length of first interview (Log) & & & & $0.023[0.018]$ \\
\hline First interview within 2 weeks & & & & $0.027[0.031]$ \\
\hline Agreement signed & & & & $0.010[0.025]$ \\
\hline $\begin{array}{l}\text { Unemployment benefit II } \\
\text { recipients }(\log )\end{array}$ & $0.774 * *[0.059]$ & $0.767 * *[0.061]$ & $0.762 * *[0.067]$ & $0.760 * *[0.072]$ \\
\hline $\begin{array}{l}\text { Unemployment benefit II } \\
\text { recipients in neighbouring } \\
\text { regions (Log) }\end{array}$ & $-0.137[0.071]$ & $-0.132[0.075]$ & $-0.128[0.076]$ & $-0.135[0.074]$ \\
\hline Short-term unemployed (Log) & $-0.024[0.072]$ & $-0.018[0.070]$ & $-0.017[0.068]$ & $-0.025[0.076]$ \\
\hline $\begin{array}{l}\text { Short-term unemployed in } \\
\text { neighbouring regions ( } \mathrm{Log} \text { ) }\end{array}$ & $0.036[0.084]$ & $0.035[0.083]$ & $0.038[0.084]$ & $0.061[0.090]$ \\
\hline New vacancies (Log) & $0.047[0.028]$ & $0.046[0.028]$ & $0.044[0.026]$ & $0.035[0.025]$ \\
\hline $\begin{array}{l}\text { New vacancies in neighbouring } \\
\text { regions }(\mathrm{Log})\end{array}$ & $0.082[0.070]$ & $0.079[0.072]$ & $0.071[0.072]$ & $0.055[0.074]$ \\
\hline Rural regions & $0.026[0.021]$ & $0.020[0.026]$ & $0.020[0.025]$ & $0.018[0.025]$ \\
\hline Metropolitan regions & $-0.034[0.033]$ & $-0.044[0.032]$ & $-0.046[0.031]$ & $-0.050[0.030]$ \\
\hline Population (Log) & $0.170[0.087]$ & $0.171[0.084]$ & $0.174[0.093]$ & $0.194 *[0.090]$ \\
\hline Constant & $-2.931 * *[0.544]$ & $-2.925 * *[0.510]$ & $-2.935 * *[0.527]$ & $-3.176 * *[0.479]$ \\
\hline Observations & 409 & 399 & 399 & 387 \\
\hline$F$-Statistic & 8.02 & 7.92 & 12.01 & 13.72 \\
\hline Durbin-Wu-Hausman Test ( $p$-value) & 0.988 & 0.998 & 0.865 & 0.635 \\
\hline$R$-Squared & 0.973 & 0.973 & 0.973 & 0.973 \\
\hline
\end{tabular}

Standard errors are given in parentheses

Confidence intervals with $*$ and $* *$ indicate significance at a $5 \%$ and $1 \%$ level, respectively. Observations are clustered at the level of the 16 German states and weighted by the number of unemployment benefit II recipients in each region. The variables of neighbouring regions are constructed such that regions within $100 \mathrm{~km}$ are weighted inversely to their distance to the region under consideration 
Table A.4 First stage of the IV regression

\begin{tabular}{|c|c|c|c|c|}
\hline \multirow[t]{2}{*}{ Dependent variable } & \multicolumn{4}{|c|}{ Dummy variable: Approved Local Provider } \\
\hline & (1) & (2) & (3) & $(4)$ \\
\hline German County Association & $0.246^{*}[0.087]$ & $0.207 *[0.073]$ & $0.166^{* *}[0.048]$ & $0.187 * *[0.051]$ \\
\hline Specialised case management & & $-0.245 * *[0.059]$ & $-0.177 * *[0.046]$ & $-0.162 * *[0.042]$ \\
\hline Own vacancy recruitment service & & & $0.380 * *[0.049]$ & $0.368 * *[0.050]$ \\
\hline Integrated matching approach & & & $-0.062[0.076]$ & $-0.090[0.073]$ \\
\hline Length of first interview (Log) & & & & $-0.045[0.043]$ \\
\hline First interview within 2 weeks & & & & $-0.200 * *[0.049]$ \\
\hline Agreement signed & & & & $0.121[0.068]$ \\
\hline $\begin{array}{l}\text { Unemployment benefit II } \\
\text { recipients }(\log )\end{array}$ & $-0.060[0.096]$ & $-0.086[0.093]$ & $-0.128[0.072]$ & $-0.145^{*}[0.068]$ \\
\hline $\begin{array}{l}\text { Unemployment benefit II } \\
\text { recipients in neighbouring } \\
\text { regions (Log) }\end{array}$ & $-0.110[0.110]$ & $-0.038[0.097]$ & $0.001[0.096]$ & $0.001[0.103]$ \\
\hline Short-term unemployed (Log) & $-0.133[0.080]$ & $-0.038[0.068]$ & $-0.041[0.067]$ & $-0.053[0.073]$ \\
\hline $\begin{array}{l}\text { Short-term unemployed in } \\
\text { neighbouring regions (Log) }\end{array}$ & $0.093[0.085]$ & $0.044[0.073]$ & $-0.012[0.059]$ & $-0.043[0.071]$ \\
\hline New vacancies $(\log )$ & $-0.302 *[0.122]$ & $-0.235 *[0.104]$ & $-0.136[0.076]$ & $-0.126[0.076]$ \\
\hline $\begin{array}{l}\text { New vacancies in neighbouring } \\
\text { regions }(\log )\end{array}$ & $-0.044[0.098]$ & $-0.063[0.097]$ & $-0.062[0.084]$ & $-0.033[0.087]$ \\
\hline Rural regions & $-0.118[0.059]$ & $-0.100[0.054]$ & $-0.046[0.055]$ & $-0.054[0.060]$ \\
\hline Metropolitan regions & $-0.032[0.061]$ & $-0.050[0.054]$ & $-0.041[0.053]$ & $-0.008[0.056]$ \\
\hline Population (Log) & $0.457 *[0.179]$ & $0.308[0.175]$ & $0.279[0.176]$ & $0.279[0.171]$ \\
\hline Constant & $-1.407 *[0.659]$ & $-0.557[0.626]$ & $-0.522[0.784]$ & $-0.030[0.781]$ \\
\hline Observations & 409 & 399 & 399 & 387 \\
\hline$R$-Squared & 0.266 & 0.359 & 0.529 & 0.555 \\
\hline
\end{tabular}

Standard errors are given in parentheses

Confidence intervals with $*$ and $* *$ indicate significance at a $5 \%$ and $1 \%$ level, respectively. Observations are clustered at the level of the 16 German states and weighted by the number of unemployment benefit II recipients in each region. The variables of neighbouring regions are constructed such that regions within $100 \mathrm{~km}$ are weighted inversely to their distance to the region under consideration 
Table A.5 IV-Estimates based on job finding rates of unemployment benefit II recipients

\begin{tabular}{|c|c|c|c|c|}
\hline \multirow[t]{2}{*}{ Dependent variable } & \multicolumn{4}{|c|}{ Log job finding rates of unemployment benefit II recipients } \\
\hline & (1) & (2) & (3) & (4) \\
\hline Approved Local Provider & $-0.005[0.011]$ & $-0.007[0.013]$ & $-0.011[0.018]$ & $-0.014[0.018]$ \\
\hline Specialised case management & & $-0.004[0.003]$ & $-0.004[0.003]$ & $-0.004[0.003]$ \\
\hline Own vacancy recruitment service & & & $0.003[0.007]$ & $0.004[0.007]$ \\
\hline Integrated matching approach & & & $0.004[0.003]$ & $0.005[0.004]$ \\
\hline Length of first interview (Log) & & & & $0.003[0.002]$ \\
\hline First interview within 2 weeks & & & & $0.003[0.004]$ \\
\hline Agreement signed & & & & $0.001[0.003]$ \\
\hline $\begin{array}{l}\text { Unemployment benefit II } \\
\text { recipients (Log) }\end{array}$ & $0.020 *[0.008]$ & $0.019 *[0.009]$ & $0.018[0.009]$ & $0.018[0.010]$ \\
\hline $\begin{array}{l}\text { Unemployment benefit II } \\
\text { recipients in neighbouring } \\
\text { regions (Log) }\end{array}$ & $-0.017[0.008]$ & $-0.016[0.009]$ & $-0.015[0.009]$ & $-0.016[0.009]$ \\
\hline Short-term unemployed (Log) & $-0.003[0.009]$ & $-0.002[0.008]$ & $-0.002[0.008]$ & $-0.003[0.009]$ \\
\hline $\begin{array}{l}\text { Short-term unemployed in } \\
\text { neighbouring regions ( } \log )\end{array}$ & $0.004[0.010]$ & $0.004[0.010]$ & $0.004[0.010]$ & $0.007[0.011]$ \\
\hline New vacancies $(\log )$ & $0.005[0.004]$ & $0.005[0.004]$ & $0.005[0.003]$ & $0.004[0.003]$ \\
\hline $\begin{array}{l}\text { New vacancies in neighbouring } \\
\text { regions (Log) }\end{array}$ & $0.010[0.008]$ & $0.009[0.009]$ & $0.008[0.009]$ & $0.006[0.009]$ \\
\hline Rural regions & $0.004[0.003]$ & $0.004[0.003]$ & $0.004[0.003]$ & $0.004[0.003]$ \\
\hline Metropolitan regions & $-0.009 *[0.004]$ & $-0.010 *[0.004]$ & $-0.010 *[0.004]$ & $-0.010 *[0.004]$ \\
\hline Population (Log) & $0.019[0.011]$ & $0.018[0.011]$ & $0.019[0.012]$ & $0.021[0.011]$ \\
\hline Constant & $0.287 * *[0.067]$ & $0.291 * *[0.063]$ & $0.290 * *[0.065]$ & $0.264 * *[0.060]$ \\
\hline Observations & 409 & 399 & 399 & 387 \\
\hline$F$-Statistic & 8.02 & 7.92 & 12.01 & 13.72 \\
\hline Durbin-Wu-Hausman Test ( $p$-value) & 0.831 & 0.825 & 0.714 & 0.537 \\
\hline$R$-Squared & 0.721 & 0.720 & 0.720 & 0.719 \\
\hline
\end{tabular}

Standard errors are given in parentheses

Confidence intervals with $*$ and $* *$ indicate significance at a $5 \%$ and $1 \%$ level, respectively. Observations are clustered at the level of the 16 German states and weighted by the number of unemployment benefit II recipients in each region. The variables of neighbouring regions are constructed such that regions within $100 \mathrm{~km}$ are weighted inversely to their distance to the region under consideration 


\section{References}

Boockmann, B., Thomsen, S.L., Walter, T., Göbel, C., Huber, M.: Should welfare administration be centralized or decentralized? Evidence from a policy experiment. IAW discussion papers Nr. 69 (2010)

Entorf, H.: Mismatch Explanations of European Unemployment: A Critical Evaluation. Springer, Berlin (1998)

European Commission: Approaches of public employment services (PES) to long-term unemployment. Draft report from seminar in Budapest, 22-24, March 2006, DG Employment, Social Affairs and Equal Opportunities

European Commission: The role of the public employment services related to 'flexicurity' in the European labour markets. In: Policy and Business Analysis, DG Employment, Social Affairs and Equal Opportunities (2009)

Fahr, R., Sunde, U.: Regional dependencies in job creation: an efficiency analysis for Western Germany. Appl. Econ. 38, 1193-1206 (2005)

Genova, A.: Integrated services in activation policies in Finland and Italy: a critical appraisal. Soc. Policy. Soc. 7(3), 379-392 (2008)

Gross, D.: Aggregate job matching and returns to scale in Germany. Econ. Lett. 56, 243-248 (1997)
Jacobi, L., Kluve, J.: Before and after the Hartz reforms: the performance of active labour market policy in Germany. Z. Arb.markt Forsch. 1, 45-64 (2007)

Lindsay, C., McQuaid, R.W.: Inter-agency cooperation in activation: comparing experiences in three vanguard active welfare states. Soc. Policy. Soc. 7(3), 353-365 (2008)

OECD: Benefits and Wages: OECD Indicators. Paris (2004)

Christian Holzner born in 1976, holds since autumn 2010 an interim professorship for public economics at the economics department of the University of Munich. He studied economics at the University of Bamberg, the University of Essex in England and did his Ph.D. at the University of Munich in 2005. During his Ph.D. and up till now he works at the Ifo Institute in the department social policy and labour markets.

Sonja Munz born in 1964, holds since autumn 2009 a full professorship for applied economic research at the tourism department of the University of Applied Science Munich. She studied sociology and economics at the University of Munich and did her Ph.D. at the University of Augsburg in 2008. From 1993 until 2009 she worked at the Ifo Institute in the department social policy and labour markets. 